This item was submitted to Loughborough's Research Repository by the author.

Items in Figshare are protected by copyright, with all rights reserved, unless otherwise indicated.

\title{
Temporal effects of enhanced fine sediment loading on macroinvertebrate community structure and functional traits
}

PLEASE CITE THE PUBLISHED VERSION

https://doi.org/10.1016/j.scitotenv.2017.04.096

PUBLISHER

(C) Elsevier

VERSION

AM (Accepted Manuscript)

\section{PUBLISHER STATEMENT}

This work is made available according to the conditions of the Creative Commons Attribution-NonCommercialNoDerivatives 4.0 International (CC BY-NC-ND 4.0) licence. Full details of this licence are available at: https://creativecommons.org/licenses/by-nc-nd/4.0/

\section{LICENCE}

CC BY-NC-ND 4.0

\section{REPOSITORY RECORD}

Mathers, Kate L., Stephen P. Rice, and Paul J. Wood. 2019. "Temporal Effects of Enhanced Fine Sediment Loading on Macroinvertebrate Community Structure and Functional Traits". figshare. https://hdl.handle.net/2134/24816. 
1 Working title: Temporal effects of enhanced fine sediment loading on

2 macroinvertebrate community structure and functional traits

3

4 Kate L. Mathers*, Stephen P. Rice and Paul J. Wood

5 Department of Geography, Centre for Hydrological and Ecosystem Science,

6 Loughborough University, Loughborough, UK

7 Author for Correspondence

8 Kate Mathers

9 Centre for Hydrological and Ecosystem Science

10 Department of Geography

11 Loughborough University

12 Loughborough Leicestershire

13 LE11 3TU

14 UK

15

16 Email:- k.mathers@lboro.ac.uk

20

21

22

23

24

25

26

27

28

29 
Temporal effects of enhanced fine sediment loading on macroinvertebrate community structure and functional traits

Mathers, K.L, Rice, S.P. and Wood, P.J.

33

34

Abstract

35

Deposition of fine sediment that fills interstitial spaces in streambed substrates is widely acknowledged to have significant negative effects on macroinvertebrate communities, but the temporal consistency of clogging effects is less well known. In this study the effects of experimentally enhanced fine sediment content on aquatic invertebrates were examined over 126 days in two lowland UK streams. Taxonomic approaches indicated significant differences in macroinvertebrate community structure associated with sediment treatment (clean or sedimented substrates), although the effects were variable on some occasions. The degree of separation between clean and sedimented communities was strong within 7 of the 9 sampling periods with significant differences in community composition being evident. EPT taxa and taxon characterised as sensitive to fine sediment demonstrated strong responses to enhanced fine sediment loading. In marked contrast, faunal traits did not facilitate the detection of enhanced fine sediment loading. More widely, the study highlights the temporal dynamics of sedimentation effects upon macroinvertebrate communities and the need to consider faunal life histories when examining the effects of fine sediment loading pressures on lotic ecosystems.

Keywords: colmation, sedimentation, sediment clogging, community composition, life-history traits, colonisation. 


\section{Introduction}

64 Increased instream fine sediment loading is widely regarded as a global threat to ecological integrity and lotic ecosystem health, often leading to reduced macroinvertebrate diversity through direct exclusion of taxa, enhanced drift or reductions in the availability of suitable trophic resources and habitat (Larsen and Ormerod, 2010; Jones et al., 2012; Wood et al., 2016). The infiltration of fine sediment into the river (colmation / clogging) has been reported to modify benthic macroinvertebrate community structure and functioning (Descloux et al., 2013). Substrates characterised by a high proportion of fine sediment are frequently dominated by taxa with low dissolved oxygen requirements (Angradi, 1999; Zweig and Rabeini, 2001) and exhibit an absence of taxa vulnerable to fine sediment due to impairment or damage of filter-feeding apparatus or delicate gills (Wood and Armitage, 1997; Larson et al., 2009). In addition, some taxa may be excluded and unable to colonise habitats where excessive fine sediment is present, for example due to the absence of suitable materials for case building by caddisfly larvae (Higler, 1975; Urbanič et al., 2005). Some functional feeding groups may also be disadvantaged by enhanced fine sediment loading, due to reduced food quality or impaired access to food resources, notably for algal scrapers and filter feeders (Rabeni et al., 2005; Kreutzweiser et al., 2005). This may lead to shifts in community structure towards those dominated by deposit feeders (Relyea et al., 2000).

Some fauna respond to fine sediment deposition pressures as a function of their morphological characteristics and functional traits (Lamouroux et al., 2004; Bona et al., 2016; Doretto et al., 2017). Recently there has been a growing focus on the incorporation of faunal traits within biomonitoring tools to elucidate on the changes that occur to invertebrate community structure in freshwater ecosystems (Menezes et al., 2010; Göthe et al., 2016; Pilière et al., 2016). Biological traits are based on the habitat model concept (Southwood, 1977), and therefore community traits may reflect spatial and temporal variations in environmental factors (Townsend and Hildrew, 1994). Trait composition can also be used to identify sources of environmental impairment associated with anthropogenic and natural stressors which act as 'filters', selecting taxa with relevant adaptive traits. Consequently, some traits may be particularly sensitive to environmental pressures and it is this possibility that has led to the increasing application of biological traits within biomonitoring tools 
96 (Statzner et al., 2004; Friberg. 2014; Turley et al., 2016). However, relatively little

97 information exists regarding how macroinvertebrate faunal traits respond to instream

98 fine sediment loading and the limited studies in this area to date have yielded

99 variable results (e.g. Buendia et al., 2013; Descloux et al., 2014).

100 The majority of studies conducted on sedimentation to date have focussed on

101 artificial enhanced fine sediment loads (Suren and Jowett, 2001; Larsen et al., 2011)

102 or have been associated with heavily sedimented river beds (Matthaei et al., 2010;

103 Wagenhoff et al., 2012). A small number of studies have experimentally manipulated

104 the volume of fine sediment within the substrate directly through the application of

105 faunal colonisation devices, but these studies have typically examined the effects at

106 a single point in time (Bo et al., 2007; Larsen et al., 2011; Pacioglu et al., 2012;

107 Descloux et al., 2013; 2014). There is an absence of research that considers the

108 temporal variability of fine sediment effects on macroinvertebrate communities and

109 the value of life history traits for understanding and monitoring these effects.

110 Species phenology within a community affects the composition of

111 macroinvertebrates observed at differing times of the year (Delucchi and Peckarsky,

112 1989; Murphy and Giller, 2000), and may confound biomonitoring assessments if not

113 acknowledged (Clarke, 2013; Carlson et al., 2013). Temporal and spatial

114 heterogeneity of hydrological regimes is also a fundamental process in shaping

115 riverine macroinvertebrate communities (Dewson et al., 2007; Monk et al., 2008).

116 Natural streams are typically characterised by stable baseflow conditions punctuated

117 periodically by flow disturbances. These flow disturbances have important

118 implications for fine sediment dynamics, initiating entrainment of fine material stored

119 in the channel and increasing suspended sediment concentrations (Leopold et al.,

120 1964; Bond and Downes, 2003). The interaction between flow and fine sediment

121 dynamics (entrainment, suspension and depositional processes) has been identified

122 as a primary factor which influences the turnover of taxa within macroinvertebrate

123 communities (Rempel et al., 2000; Buendia et al., 2014; Jones et al., 2015).

124 Consequently, as a result of temporal variability in flow and species assemblages, it

125 follows that it is important to consider the effects of sediment loading over time. 
126

127

128

129

130

131

132

133

134

135

136

137

138

139

140

141

142

143

144

145

146

147

148

149

150

151

152

153

154

155

156

This study is the first to specifically consider the temporal variability of experimentally manipulated fine sediment loading on macroinvertebrate communities at a fine temporal resolution (weeks). The following research questions were addressed:

(i) Is the effect of increased fine sediment loading on macroinvertebrate communities consistent temporally?

(ii) Which taxa and functional traits are associated with enhanced fine sediment loading?

(iii) Are the observed effects of enhanced fine sediment loading on macroinvertebrate communities evident and consistent for both taxonomic and faunal trait compositions?

\section{Materials and methods}

\subsection{Field sites}

The study took place on two small lowland rivers in Rutland, UK; the River Gwash $\left(52^{\circ} 38^{\prime} \mathrm{N}, 00^{\circ} 44^{\prime} \mathrm{W}\right)$ and the River Chater $\left(52^{\circ} 37^{\prime} \mathrm{N}, 00^{\circ} 44^{\prime} \mathrm{W}\right)$. Sites were selected to be as broadly comparable in physical characteristics (channel size, water chemistry, altitude and geology) as possible. Both river channels were characterised by a riffle - pool morphology (channel width $2.9-6.5 \mathrm{~m}$ ). Catchment geology was dominated by Jurassic mudstones and sandstones (British Geological Survey, 2008) and study sites were located in arable farmland. Close to the catchment outlets, mean daily flows were $0.18 \mathrm{~m}^{3} \mathrm{~s}^{-1}$ and $0.52 \mathrm{~m}^{3} \mathrm{~s}^{-1}$ for the River Gwash and Chater respectively (record 1978-2015; NRFA, 2017). Subsurface bed material (based on four pooled individual McNeil samples from two riffles per site, average sample weight $20.01 \mathrm{~kg}$ [McNeil and Ahnell, 1964]) indicated similar grain size distributions (GSD) between sites; with both being naturally characterised by a moderate fine sediment content (mass < 2mm; Gwash 20\% and Chater 28.8\%). Hydrological data from local gauging stations indicated that the study coincided with periods of stable flow punctuated by increased river stage associated with summer rainfall events (Figure 1). 


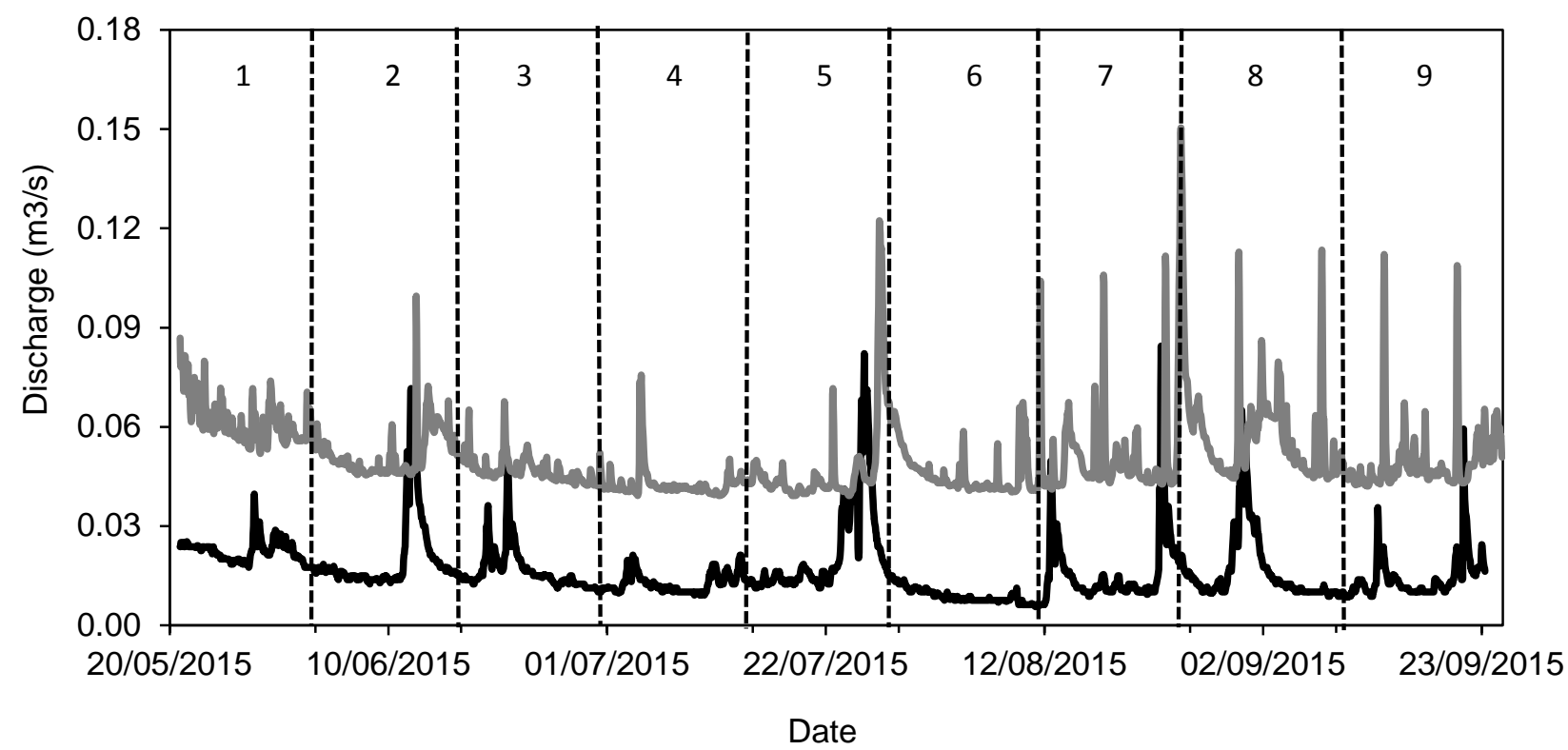

165

Date

Figure 1. River discharge (hourly average $\mathrm{m}^{3} \mathrm{~s}^{-1}$ ) for the River Gwash (black) and River Chater (grey) Rutland, UK during the sampling campaign. Dashed lines indicate the two week sampling periods $\left(21^{\text {st }}\right.$ June $-24^{\text {th }}$ September 2015$)$.

169

\subsection{Colonisation columns}

171 Macroinvertebrate colonisation columns were installed at the two sample sites.

172 These comprised PVC cylinders (diameter $65 \mathrm{~mm}$, height $200 \mathrm{~mm}$ ) perforated with

173 twelve horizontal holes (diameter $6 \mathrm{~mm}$ ) to permit horizontal and vertical exchange

174 of water and the free movement of macroinvertebrates and fine sediment (Fraser et

175 al; 1996; Pacioglu et al., 2012; Descloux et al; 2013; Mathers and Wood, 2016). All

176 columns were filled with a pre-washed gravel framework collected from each of the

177 respective sample sites (truncated at $8 \mathrm{~mm}$ ). This substrate was enclosed in a net

178 bag (7 $\mathrm{mm}$ aperture) within each column. Columns were assigned to one of two

179 treatments; a) clean substrates which were free from fines upon installation or; b)

180 heavily sedimented substrates comprising gravel and $250 \mathrm{~g}$ of fine sand (63-2000

$181 \mu \mathrm{m})$. Preliminary tests indicated that this volume of sand filled $100 \%$ of interstitial

182 volume. For the sedimented columns, a circular disk (64 mm diameter) was attached

183 to the mesh bag to effectively seal the base of the column and reduce the loss of fine 184 sediment vertically into the riverbed. 
185 Columns were inserted into the river bed by placing the PVC cylinders onto a steel 186 pipe (35 $\mathrm{mm}$ diameter) that was driven into the river bed sediments until a sufficient 187 depth was obtained to insert it flush with the substrate surface $(200 \mathrm{~mm})$. The 188 surrounding stream bed remained unchanged and consisted of non-uniform cobbles and gravel. Columns were left in-situ for the entire sampling campaign, but every 14 days the gravel netting bag was removed and replaced without disturbing the surrounding gravel framework. At the end of each 14-day sampling period, the net bag (containing the substrate and macroinvertebrates) was carefully removed, placed in a sample bag and preserved in 10\% formaldehyde for subsequent processing in the laboratory. Empty columns were then replaced immediately with the corresponding gravel bag treatment (clean or sedimented).

Colonisation columns were installed every 14 days between $21^{\text {st }}$ May and $24^{\text {th }}$ September 2015 providing a 126 day record (9 sample sets). A time period of 14days was adopted because preliminary tests indicated that this represented sufficient time to allow for colonisation by macroinvertebrates whilst minimising the amount of fine sediment lost during occasional high flows (See Supplementary Material and Figure S1). At each riffle site (three on the Gwash and two on the Chater; one until the fourth sampling set), four columns of each type (clean or sedimented) were installed providing a total of 20 replicates (16 initially for three sample sets) for each 14-day sampling period. In total 162 clean and 163 sedimented substrate samples were examined ( 6 clean and 5 sedimented samples were lost or not retrieved during the field campaign). Two additional sampling timeframes (ca one month: 28 days and ca two months: 56 days) were examined to capture potential temporal variability in environmental conditions (i.e. rising or falling discharge or suspended sediment concentrations) and to confirm the most appropriate time-frame to consider in the main study and are presented in Supplementary material (Figure S1).

\section{$212 \quad 2.3$ Laboratory procedures and statistical analysis}

213 Within the laboratory, the contents of the column bags were passed through a sieve nest (4 and $2 \mathrm{~mm}$ sieves) to remove larger gravel clasts. The remaining material was passed through a $250 \mu \mathrm{m}$ sieve and processed for invertebrates. All macroinvertebrates were identified to the lowest taxonomic level possible usually

217 species or genus with the exception of Oligiochetea (order), Diptera families 
218 (including Ephydridae, Ptychopteridae, Chironomidae, Psychodidae, Simuliidae,

219 Ceraptogonidae and Stratiomyidae), Sphaeriidae and Zonitidae (family) and

220 Ostracoda, Hydracarina and Collembola which were recorded as such.

221 Compositional differences in communities between the two sediment treatments

222 were examined via non-metric multidimensional scaling (NMDS) using Bray-Curtis

223 similarity coefficients for the entire data set and for each individual sampling period.

224 This approach enabled an examination consistency in the community effects or if

225 they varied over time as a function of environmental conditions (i.e. discharge over

226 the14-day period). A One way ANOSIM (Analysis of Similarities) was used to

227 examine differences in the communities amongst sediment treatments for the overall

228 data set and for each individual sample set (1-9) using a random Monte Carlo

229 permutations test (999 permutations). Both P and R ANOSIM values were examined,

230 with $\mathrm{R}$ values $>0.75$ indicating strong separation amongst groups, $R=0.75-0.25$

231 indicating separate groups with overlapping values and $R<0.25$ as barely

232 distinguishable groups (Clarke and Gorley, 2006). Taxa contributing to the

233 divergence of communities were identified through the application of the similarity

234 percentage (SIMPER). The top six taxa identified as driving dissimilarity between

235 clean and sedimented communities were selected for further detailed analysis of

236 their sensitivity to fine sediment.

237 The functional composition of macroinvertebrate communities was determined

238 through the assignment of fauna into 6 categories which were comprised of 44

239 biological traits from the Tachet et al., (2010) database (Table 1). Categories

240 represent grouping features including 'maximum body size' and 'functional feeding

241 group', whilst traits signify modalities residing within these such as 'shredder' or

242 'filter-feeder'. Traits were assigned based on a fuzzy-coding approach with scores

243 ranging from zero (indicating no affinity) to three or five (the strongest affinity based

244 on available literature; Chevene et al., 1994). Affinity scores were subsequently

245 rescaled as proportions for each category $($ sum $=1)$ for each taxon. Chironomidae

246 and all taxa recorded at a coarser resolution than family-level were excluded due to

247 the large species diversity within the groups. To produce a trait abundance matrix,

248 taxon-trait categories were multiplied by $\log (x+1)$ transformed abundances (Larsen

249 and Ormerod, 2010; Descloux et al., 2014; White et al., 2017).. Functional

250 compositional differences for each sampling set were visualised via NMDS plots. All 
251 ordination analyses were performed in PRIMER Version 7.0.11 (PRIMER-E Ltd,

252 Plymouth, UK).

253 The macroinvertebrate communities of the two study streams represent distinct 254 community structures as a function of signal crayfish invasion within the River

255 Gwash in 1996 (global ANOSIM p < 0.001; Mathers et al. 2016). Following invasion, 256 signal crayfish typically have significant, long-term and persistent effects on macroinvertebrate communities (McCarthy et al., 2006; Twardochleb et al., 2013). As a result, preliminary analyses were conducted on the individual rivers to determine whether the gross effects of sediment loading were comparable for the communities.

260 This analysis took the form of temporal group centroid (clean and sedimented) NMDS plots using Bray-Curtis similarity coefficients. These results indicated that the temporal trajectory of community change and sedimentation effects were comparable for both community composition and biological traits. Taxonomic plots determined a significant sediment treatment effect for both rivers (ANOSIM Gwash $p$ $=0.035$; Chater $p=0.012$; Figure S2) whilst biological traits indicated no divergence in trait composition (ANOSIM Gwash $p=0.143$; Chater $p=0.104$ ). Consequently, as both river communities reacted in a similar manner to sediment loading, the final analyses outlined above were conducted on the combined datasets.

Community abundance, taxa richness and richness of Ephemeroptera, Plecoptera and Trichoptera (EPT) taxa were derived from the raw data. Abundances of taxa characterised as sensitive to sediment according to sensitivity weights provided in the Empirically-weighted Proportion of Sediment-sensitive Invertebrates index (E-PSI;

273 Turley et al., 2016) were also calculated for each sample. To examine statistical

274 differences associated with sediment treatment for individual taxon abundances (as

275 previously selected from the global SIMPER), generalised linear mixed effects 276 models were employed (GLMMs). Models were fitted using the 'Ime4' package in R 277 version 3.2.2 using the 'glmer' function (R development Core Team, 2015). To 278 examine differences associated with the volume of fine sediment, sediment 279 treatment was specified as a fixed factor and riffle was nested within site as a random factor (based on columns at individual riffles and sites being less independent of each other). Models were fitted using a Poisson error distribution and log link structure. Linear mixed models were fitted to the functional traits and community metrics using the 'nlme' package and 'Ime' function. The same model 
284 structure (outlined above) was employed and the models were fitted using the 285 restricted maximum likelihood (REML) estimation function. A Bonferroni correction 286 was applied to all models to account for the large number of models constructed.

Table 1. Macroinvertebrate functional traits examined within this study (taken from Tachet et al., 2010).

\begin{tabular}{ll}
\hline Category & Trait \\
\hline Maximal potential size & $<0.25 \mathrm{~cm}$ \\
& $>0.25-0.5 \mathrm{~cm}$ \\
& $>0.5-1 \mathrm{~cm}$ \\
& $>1-2 \mathrm{~cm}$ \\
& $>2-4 \mathrm{~cm}$ \\
& $>4-8 \mathrm{~cm}$ \\
& $>8 \mathrm{~cm}$ \\
\hline Reproduction & Ovoviviparity \\
& Isolated, free eggs \\
& Isolated eggs, cemented \\
& Clutches, cemented eggs \\
& Clutches, free \\
& Clutches, in vegetation \\
& Asexual \\
\hline Respiration & Gill \\
& Plastron \\
Spiracle \\
Hydrostatic vesicle \\
Tegument \\
Flier \\
Surface swimmer \\
Full water swimmer \\
Crawler \\
Burrower \\
Interstitial \\
Temporarily attached \\
Permanently attached \\
Absorber \\
Deposit feeder \\
Shredder \\
Scraper \\
Filter-feeder \\
Piercer \\
Predator \\
Parasite \\
Coarse substrates \\
Gravel \\
Sand \\
Silt \\
Macrophytes \\
Microphytes \\
Twigs / roots \\
Organic detritus \\
Mud \\
\hline
\end{tabular}




\subsection{Community composition associated with sediment treatment}

29063 taxa were recorded in the clean sediment treatment (mean 6.79 taxa per sample, range 2-13) and 58 taxa in the sedimented treatment (mean 6.94 taxa per sample, range 1-16). A total of 9,656 individuals were recorded in the clean sediment samples (mean 59.98 individuals per sample, range 14-136) and 8,078 in the sedimented samples (mean 49.86 individuals per sample, range 9-168). Communities in the clean sediments were dominated by Gammarus pulex (67.68\% of total abundance), Chironomidae (9.67\%) and Potamopyrgus antipodarum (6.73\%).

297 The most abundant taxa within the sedimented substrates were G. pulex (53.50\%), 298 Chironomidae (12.17\%) and Oligochaeta (10.84\%). A total of 11 taxa were unique to 299 clean sediments (3 Gastropoda, 2 Trichoptera, 2 Diptera, 1 Ephemeroptera, 1

300 Hirudinea, 1 Coleoptera and 1 Ostrocoda) and 2 to the sedimented substrates (1 301 Tricladida, 1 Trichoptera) although these occurred at low abundances (constituting 29 and 2 individuals respectively).

303 Non-metric Multi-Dimensional Scaling (NMDS) ordination diagrams indicated distinct 304 clusters of macroinvertebrate communities associated with sediment treatment on 305 seven out of the nine sampling occasions (Figure 2). The degree of separation between the groups varied over time with highly significant divergence in sets 2, 4, 5 and 7 (ANOSIM $p<0.005$; Figure $2 b, d, e \& g$ ), and moderate separation in set 1 (ANOSIM $p=0.041$; Figure $2 a$ ), whilst a number of sets were less significantly dispersed; sets 6 and 8 (ANOSIM $P<0.05$; Figures $2 f \& h$; Table 2). Two 14-day periods, sets 3 and 9 (Figure $2 c \&$ i), demonstrated no significant differences in the macroinvertebrate communities inhabiting the two substrate types. The global dataset indicated some divergence of communities when all timeframes were considered ( $p<0.0001$; ANOSIM) although analysis of the $R$ value $(R=0.083)$, indicated that the groups were barely distinguishable from each other (Figure 2j). This low degree of separation reflects the varying stability of these patterns between the individual sample sets. The top six taxa driving dissimilarity were Oligochaeta

317 (5.75\% dissimilarity), Chironomidae (5.42\%), P. antipodarum (5.12\%), G. pulex 318 (4.49\%), Dicranata sp. (3.10\%) and Habrophlebia fusca (2.70\%). 


\section{ANOSIM $\mathrm{p}=0.002$}

334

335

336 
Table 2. Summary of ANOSIM values over time by sediment treatment .

\begin{tabular}{ccc}
\hline Set & r value & p value \\
\hline $\mathbf{1}$ & 0.078 & 0.041 \\
$\mathbf{2}$ & 0.231 & 0.002 \\
$\mathbf{3}$ & -0.003 & 0.457 \\
$\mathbf{4}$ & 0.107 & 0.003 \\
$\mathbf{5}$ & 0.127 & 0.001 \\
$\mathbf{6}$ & 0.096 & 0.012 \\
$\mathbf{7}$ & 0.166 & 0.002 \\
$\mathbf{8}$ & 0.082 & 0.022 \\
$\mathbf{9}$ & -0.018 & 0.664 \\
\hline
\end{tabular}

352

\subsection{Biological traits associated with sediment treatment}

354 NMDS ordination analysis indicated no clear and consistent differentiation between sediment treatments over time when trait community composition was examined (Figure 3). Trait based community composition demonstrated some degree of separation in a number of instances (i.e. sample sets 3, 4, 6; Figures $3 c, d \& f$ ), but 358 this was not consistent or clear for all sample sets (i.e. sample sets 1, 5; Figures 3a 359 \& e). Divergence in communities was most marked during sample set 6 which also corresponds to the only statistically significant difference in trait community composition (ANOSIM p $=0.037$; Figure $3 f$ ). When individual traits were considered, eight trait modalities varied significantly as a function of sediment treatment. The trait profile of locomotion was the most significant with individuals characterised as being

364 full water swimmers $\left(\mathrm{t}_{10,320}=-4.53, \mathrm{p}<0.001 ; \mathrm{LME}\right)$, crawlers $\left(\mathrm{t}_{20,310}=-3.224, \mathrm{p}=\right.$ $3650.001)$ or interstitial dwellers $\left(t_{10,320}=-4.93, p=<0.001\right)$ demonstrating significant 366 reductions for the sedimented treatment. Species demonstrating ovoviviparity $\left(t_{10,320}\right.$ $367=-4.51, p=<0.001)$, respiring via plastron $\left(t_{6,320}=-4.90, p=<0.001\right)$ or spiracles $368\left(\mathrm{t}_{10,320}=-3.12, \mathrm{p}=<0.001\right)$ and $/$ or demonstrating shredder affinities $\left(\mathrm{t}_{10,320}=-3.43\right.$, $369 \mathrm{p}=<0.001$ ) all demonstrated a reduction within sedimented substrates. Maximum 370 potential size of individuals also varied between treatments with a decline in larger

371 taxon characterised with a body size of $1-2 \mathrm{~cm}$ within the sedimented columns $\left(\mathrm{t}_{10,320}\right.$ $372=-3.59, p=<0.001)$. 


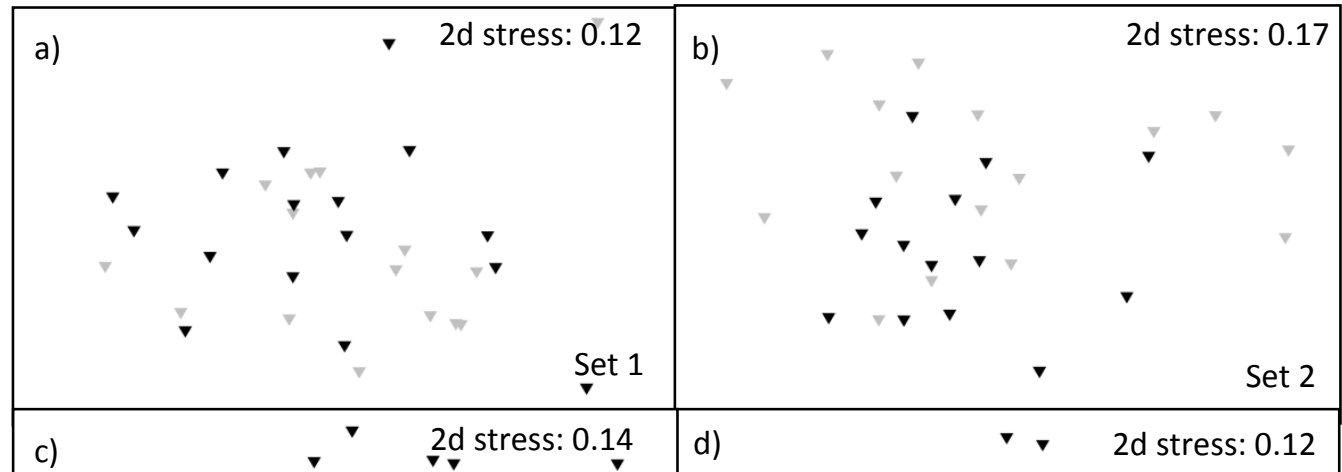

378

379

380

381

382

383

384

385

386

387

388

389

390

391

392

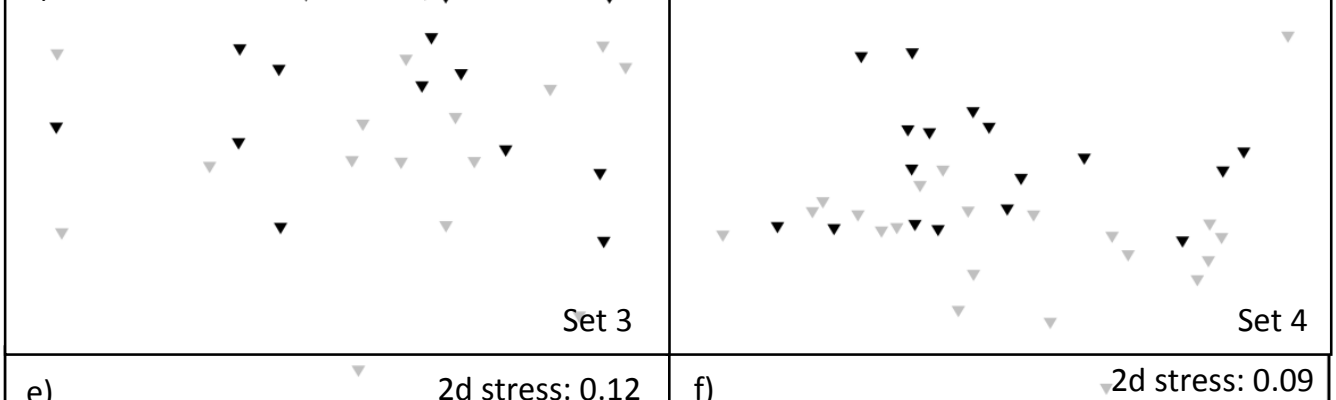

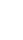
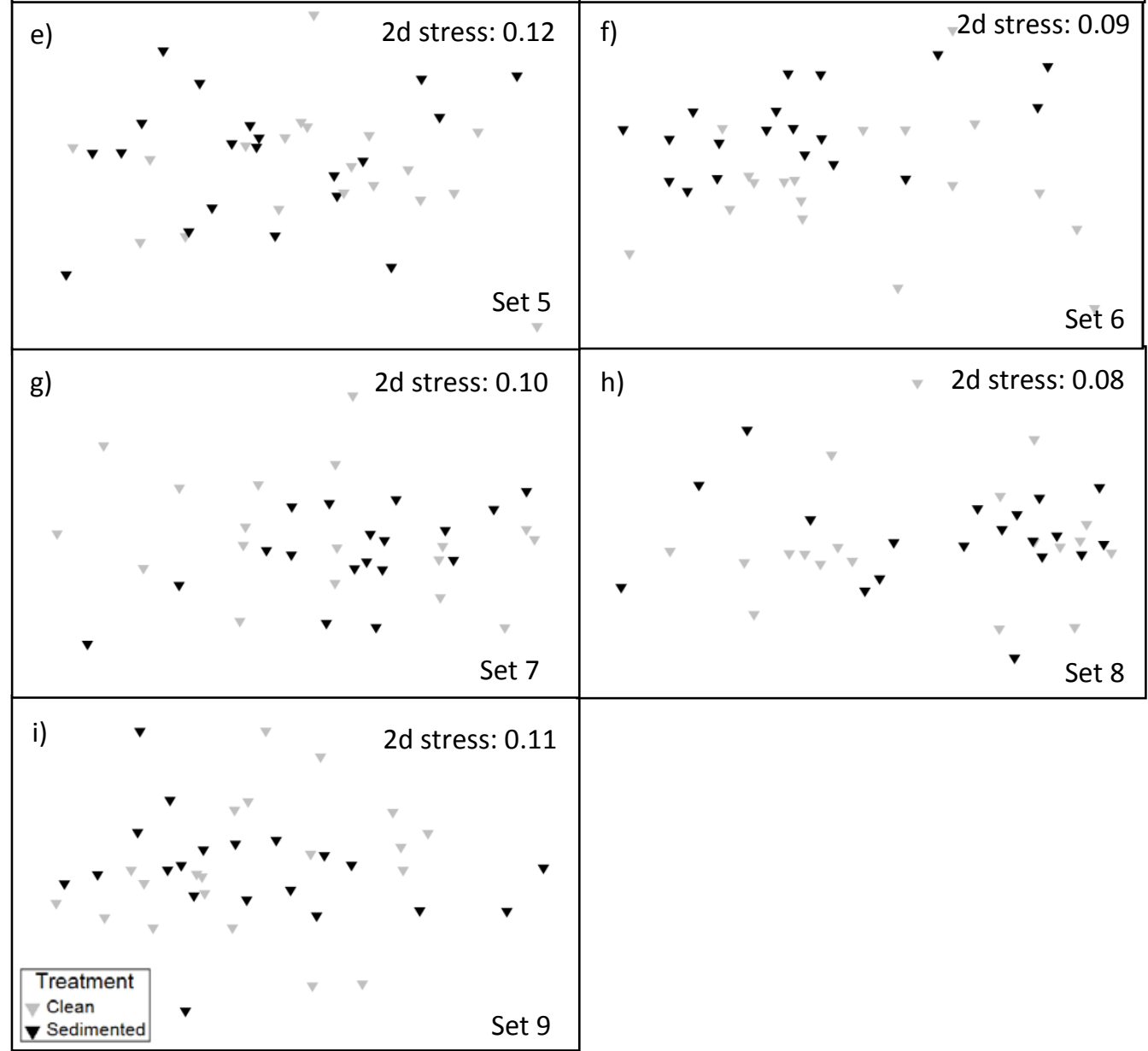

393 Figure 3. Non-metric multidimensional scaling (NMDS) of macroinvertebrate community 394 functional traits from the River Gwash and River Chater by sediment treatment using the 395 Bray-Curtis similarities coefficients for cylinder sets 1 - 9 (panes a-i). Grey rhombus = clean 396 cylinders and black rhombus = clogged communities. 


\subsection{Community metrics and individual taxon abundances associated with}

400 sediment treatment

401 Community abundance, taxa richness and EPT richness did not vary by sediment 402 treatment (LME $p>0.05$ ). Sediment sensitive taxa (as defined under E-PSI metric) 403 were recorded in significantly greater abundances in the clean sediments $\left(t_{10,310}=-\right.$ $4042.94, p<0.001)$. The divergence of clean and sedimented substrates was not 405 apparent during Set 1, 3 and 9 with similar abundances of sensitive taxa in both 406 treatments whilst the greatest distinction between sediment treatments was during 407 sets 4-8 (Figure 4). When individual taxon abundances were considered, Dicranota 408 sp. and Oligochaeta were found in significantly greater abundances in sedimented 409 columns $\left(Z_{6,320}=8.76, p<0.001\right.$ and $\left.Z_{6,320}=15.84, p<0.001 ; G L M M\right)$. Clean

410 sediment treatments were found to support greater abundances of the

411 ephemeropteran $H$. fusca $\left(Z_{6,320}=-6.76, p<0.001\right)$ and the amphipod $G$. pulex $\left(Z_{6,320}\right.$ $412=-20.03, p<0.001)$. No significant sediment treatment differences were determined 413 for any other taxa $(p>0.05)$ although EPT richness demonstrated significant 414 variability over time within this study $\left(t_{10,320}=-3.45, p<0.001\right.$; LME; Figure 5).

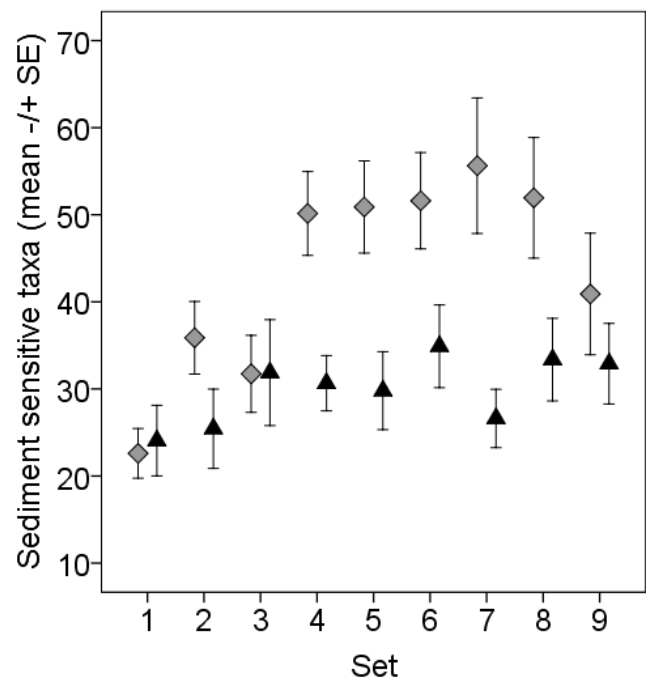

Figure 4. Mean abundances (+/- 1 SE) of sediment sensitive taxa (as defined under the EPSI index) over the nine sampling sets. Grey rhombus = clean substrates and; black triangle = sedimented substrates. 


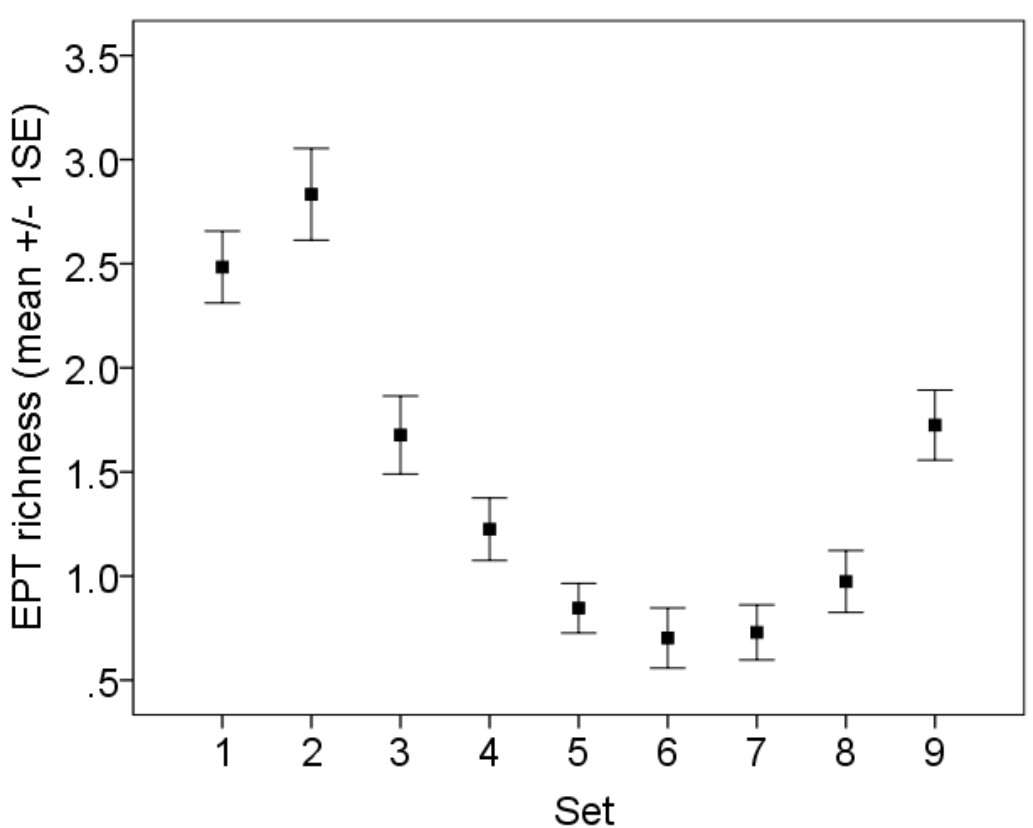

Figure 5. Mean abundances (+/- 1 SE) of EPT taxa over the nine sampling sets.

\section{Discussion}

\subsection{Macroinvertebrate community composition}

441 This study sought to examine the temporal variability of experimentally enhanced

442 fine sediment loading on macroinvertebrates communities. The results indicate 443 colonisation by macroinvertebrates may be impeded as a result of enhanced fine 444 sediment loading but that the effects vary temporally. Analysis demonstrated a 445 significant difference in macroinvertebrate community composition associated with 446 sediment treatment during seven of the nine 14-day sampling periods. However, the 447 effects of sedimentation were not temporally consistent with differences between 448 community composition being stronger in some periods and breaking down 449 completely in others.

450 No evidence was found to suggest that spate periods affected the degree of 451 separation between communities within sedimented and clean substrates. A number 452 of sample sets experienced periods with high flows (e.g. sets 6 and 8) but this did 453 not appear to have any effect on the colonisation of the sediments. Similarly, sample 454 sets which demonstrated little separation did not correspond with periods of high flow 455 (i.e. sample set 3). It is likely that the variable responses to sedimentation reflects 
456 the different life cycle characteristics and stages present in the river during the study 457 and therefore reflects natural temporal variability in the macroinvertebrate community 458 structure. The abundance of sediment sensitive taxa demonstrated a similar pattern 459 to that recorded for the taxonomic NMDS plots, with no differences in abundances 460 recorded for sets 1, 3 and 9. These changes in sediment sensitive taxa may be 461 driven by the life cycle of EPT taxa, which are particularly sensitive to fine sediment 462 within the substrate (Conroy et al . 2016) and which were temporally variable 463 abundance in richness during this study. EPT richness below a threshold of 2 taxa in 464 this study coincided with clear differences in community structure associated with the 465 sediment treatment.

466 Given the study took place during summer; discharges were naturally low and 467 favoured the deposition of fine sediments (Wood and Armitage, 1999). Consequently, 468 the dominant taxa recorded during this period are more likely to display affinities to fine sediment such as the families of Caenidae and Chironomidae (Jowett, 1997; Dewson et al., 2007). The presence of later instars of EPT taxa during the summer months may be limited due to emergence patterns, but the majority (excluding Caenidae) probably display a greater affinity for clean substrates (Sutherland et al., 473 2012) and may account for the community patterns recorded in this study. As such, 474 the implications of fine sediment deposition will be most pronounced during summer months. It is therefore vital to consider within-year temporal variation and taxon life stages when assessing the implications of fine sediment deposition on aquatic communities (Johnson et al., 2012).

478 Overall significant differences were recorded for the abundances of taxa classified as 479 sensitive to fine sediment (Turley et al., 2016). These results indicate that at the 480 patch scale, removal of fine sediments may enhance habitat complexity and thereby 481 increase the heterogeneity of instream communities. Micro-scale habitat 482 characteristics are critical in the regulation of macroinvertebrate diversity (Pardo and 483 Armitage, 1997; Lamouroux et al., 2004; Laini et al., 2014). Despite this, the majority 484 of studies conducted on fine sedimentation impacts often take a reach-scale 485 approach (e.g. Downes et al., 2006; Burdon et al., 2013) and therefore 486 understanding the importance of variable micro-scale habitat dynamics is limited. 487 Within this study clean substrates supported a greater number of unique taxa (11) 
compared to sedimented substrates (2), highlighting the importance of micro-scale

489 habitat differences for biodiversity.

490 Taxa richness, community abundance and EPT richness did not demonstrate any

491 significant differences between sediment treatments. The documented effects of fine 492 sediment on taxa richness and community abundance are not consistent in the 493 literature with some studies documenting a reduction in taxa richness (Cline et al., 494 1982; Rabeni et al., 2005) or community abundance (Armstrong et al., 2005; Larsen 495 et al., 2011) while others recorded no modification (Lenat et al., 1981; Kaller et al., 496 2004; Downes et al., 2006); and in some instances abundances have been reported 497 to increase (Matthaei et al., 2006). Streams that are characterised by low fine 498 sediment content and support a greater proportion of fine sediment sensitive taxa, 499 are likely to be more heavily affected. In contrast, rivers that are species poor may 500 not display a marked response to an increase in fine sediment.

\subsection{Taxon specific responses to fine sedimentation}

502 A small number of associations were observed between individual taxa and fine 503 sediment treatments. Sedimented substrates were characterised by significantly 504 greater abundances of two taxa that typically burrow into fine substrates; Dicranota 505 sp. and Oligochaeta (Lenat et al., 1979; Fitter and Manuel, 1986). Even at the order 506 level, Oligochaeta are widely documented to be positively correlated with fine 507 sediment (Richards et al., 1993; Waters, 1995; Angradi, 1999; Descloux et al., 2013); 508 however, the experimental effects of fine sediment for Dicranota sp. have not been 509 widely documented. The reduction of pore space in heavily sedimented and clogged 510 substrates potentially favours taxa with small body sizes (Gayraud and Phillipe, 2001;

511 Duan et al., 2009; Xu et al., 2012). In marked contrast, two species demonstrated 512 strong affinities for clean substrates; the Ephemeropteran species, Habrophlebia 513 fusca which may be vulnerable to gill damage within fine bed material (Jones et al., 514 2012) and Gammarus pulex, which although common in rivers with fine sediment 515 patches is a highly mobile taxon and may have actively sought clean sediments 516 (Wood et al., 2010; Mathers and Wood, 2016).

\subsection{Biological traits}

518 Several previous studies have suggested that macroinvertebrate community trait 519 profiles may alter as a function of habitat modifications; reflecting a filtering effect of 
520 taxa with traits sensitive to fine sediment deposition (Usseglio-Polatera et al, 2000;

521 Larsen et al., 2011; Bona et al., 2016; Doretto et al., 2017). However, when the

522 functional composition of macroinvertebrate communities was examined in this study,

523 the effects of fine sediment were not as marked as those obtained using taxonomic

524 community composition data. Differences between functional trait composition

525 associated with sediment treatment were only observed on a very limited number of

526 sampling occasions. Despite the absence of a clear community effect, a number of

527 individual traits showed a significant response to fine sediment content.

528 Locomotion modalities were the most responsive to increased fine sediment loading

529 with crawlers, swimmers and interstitial dwellers all demonstrating a reduction in

530 occurrence within sedimented substrates. Habitat trait groups have been reported to

531 display significant responses to sedimentation, with fine sediment having the

532 potential to limit access to preferred habitats (Gayraud and Philippe, 2001; Rabeni et

533 al., 2005). Interstitial pore space is an important determinant in macroinvertebrate

534 colonisation and diversity, with fine sediment clogging limiting the ability of many

535 taxa to access subsurface habitats, in particular larger organisms that require larger

536 interstitial space (Larsen and Ormerod, 2010; Mathers et al., 2014). It is therefore not

537 surprising that the number of interstitial dwellers in combination with the maximal

538 size of organisms reduced within the sedimented columns (Buendia et al., 2013;

539 Descloux et al., 2014; Milesi et al., 2016). Similarly, crawlers have been widely

540 documented to be affected by increasing fine sediment content with some studies

541 citing their reduced locomotion as a factor in their reduced abundance (Bo et al.

542 2007; Buendia et al., 2013) whilst others link their decline to negative effects on

543 respiration modalities (Rabeni et al., 2005). In contrast, the habitat group of

544 swimmers demonstrated variable responses to enhanced sediment loading, with

545 some studies documenting a decrease in richness but no effect on density (Rabeni

546 et al., 2005), whilst others saw a reduction in abundance (Larsen et al., 2011) or

547 even a positive correlation (Buendia et al., 2013). Habitat complexity prior to

548 sedimentation probably influences the magnitude of the effects recorded on the

549 invertebrate assemblage. Rivers which are naturally more heterogeneous are likely

550 to display greater effects in response to instream stressors such as fine sediment

551 deposition. 
552 Feeding modalities are often associated with fine sediment content, with increasing

553 fine sediment loads affecting the quality of trophic resources and thereby affecting

554 feeding activities (Jones et al., 2012). In contrast to the expectations of the wider

555 literature, the only taxa that demonstrated a reduction in abundance to increased fine

556 sediment content were those that displayed shredder feeding characteristics

557 (Descloux et al., 2014; Doretto et al., 2016). Similarly, respiration modalities are

558 often particularly sensitive to fine sediment with some respiratory structures being

559 significantly impaired or damaged by fine particles (Lemley, 1982; Townsend et al.,

560 2008). This study documented no significant associations with fine sediment content

561 and respiratory structures which were supported by the wider sedimentation

562 literature. Taxa which respire via plastron and spiracles demonstrated a reduction in

563 abundance in marked contrast to results reported by Logan (2007) and Archaimbault

564 et al., (2005). This biological response is primarily a function of increasing numbers

565 of the Diptera within the genus Dicranota sp. and may highlight a limitation of

566 biological trait analyses that only consider individual traits.

567 The application of biological traits in evaluating the effect of stressors has seen

568 increasing recognition, with many studies proposing that the application of trait

569 compositions may provide a better or comparable indicator for different types and

570 combinations of instream stressors than traditional taxonomic based metrics

571 (Menezes et al., 2010; White et al., 2016; Göthe et al., 2016). However, from the

572 results reported here and in a number of other studies, it is clear that further

573 research is required around the assignment of biological traits and caution should

574 therefore be applied when undertaking such analyses (Buendia et al., 2013;

575 Descloux et al., 2014). Further research is required to develop trait databases that

576 have greater applicability to the ecosystems being assessed. Currently the only

577 database available to European researchers is that by Tachet et al. (2010)

578 developed in French streams. Although applicable to other European streams, the

579 low taxonomic resolution of the database (family / genus) raises some questions

580 regarding the wider application of such an approach without some local modifications

581 as many families with multiple genus (e.g. Baetidae and Chironomidae) support

582 highly variable taxonomic responses (Monk et al., 2008). Traits are also unlikely to

583 act in isolation but rather a combination of traits will determine the response of an

584 individual species to a stressor (Pilière et al., 2016). Consequently, in future research, 
585 traits should be assessed as interacting factors within a more fully developed

586 mechanistic understanding of the observed effects of fine sediment for

587 macroinvertebrates.

\section{5. Conclusion}

589 Understanding the mechanistic implications of fine sediment upon macroinvertebrate 590 communities still remains a significant challenge. This study indicates that the effect

591 of increased fine sediment loading upon macroinvertebrate assemblages is not 592 temporally consistent with a number of sampling periods displaying no discernible 593 effects of fine sediment loading. The implications of increased fine sediment loading 594 are likely to be heavily dependent on the timing of sedimentation events relative to 595 taxon life cycles. Future studies concerned with investigating the effects of fine 596 sediment should do so with a greater awareness of the temporal dynamics of the 597 communities they are studying. Despite the increasing application of biological trait 598 composition within biomonitoring efforts, community trait profiles displayed no 599 consistent effect to fine sediment on community structure in this study. Patch scale 600 responses to fine sediment were however evident, with the two substrate treatments 601 supporting distinct communities when taxonomic composition and individual trait 602 modalities were considered. The results from this study indicate the importance of 603 recognising micro-scale habitats within the context of maximising aquatic biodiversity. 604 Further research is required to fully understand the seasonal effects of fine sediment 605 deposition and dynamics on aquatic macroinvertebrate assemblage structure and 606 function.

\section{Acknowledgements}

608 KLM acknowledges the support of a Glendonbrook doctoral studentship at 609 Loughborough University and co-funding from the Environment Agency to undertake 610 this study. Thanks to Matthew Hill who provided assistance with the fieldwork,

611 Richard Harland for providing technical and laboratory support and Samuel Dixon for 612 help in the collection of substrate. Thanks also to James White for useful discussions 613 relating to the application of functional traits within the study. The helpful and 614 constructive comments of three anonymous reviewers improved the clarity of the 615 manuscript and we are grateful for that contribution. 


\section{$617 \quad$ List of Figures}

618 Figure 1. River discharge (hourly average $\mathrm{m}^{3} \mathrm{~s}^{-1}$ ) for the River Gwash (black) and 619 River Chater (grey) Rutland, UK during the sampling campaign. Dashed lines 620 indicate the two week sampling periods $\left(21^{\text {st }}\right.$ June $-24^{\text {th }}$ September 2015$)$.

621 Figure 2. Non-metric multidimensional scaling (NMDS) of macroinvertebrate 622 community data from the River Gwash and River Chater by sediment treatment 623 using the Bray-Curtis similarities coefficients for cylinder sets 1 - 9 (panes a-i) and 624 global dataset (pane j). Grey rhombus = clean cylinders and black rhombus = 625 sedimented communities.

626 Figure 3. Non-metric multidimensional scaling (NMDS) of macroinvertebrate 627 community functional traits from the River Gwash and River Chater by sediment 628 treatment using the Bray-Curtis similarities coefficients for cylinder sets 1 - 9 (panes 629 a-i). Grey rhombus = clean cylinders and black rhombus = sedimented communities.

630 Figure 4. Mean abundances (+/- 1 SE) of sediment sensitive taxa (as defined under 631 the E-PSI index) over the nine sampling sets. Grey rhombus = clean substrates and; black triangle $=$ sedimented substrates.

633 Figure 5. Mean abundances (+/- 1 SE) of EPT taxa over the nine sampling sets. 634

\section{References}

636 Angradi, T.R., 1999. Fine sediment and macroinvertebrate assemblages in 637 Appalachian streams: a field experiment with biomonitoring applications. Journal of 638 the North American Benthological Society. 18, 49-66.

639 Archaimbault, V., Usseglio-Polatera, P. and Bossche, J.P.V., 2005. Functional 640 differences among benthic macroinvertebrate communities in reference streams of 641 same order in a given biogeographic area. Hydrobiologia, 55, 171-182.

642 Armitage, P.D. and Cannan, C.E., 2000. Annual changes in summer patterns of 643 mesohabitat distribution and associated macroinvertebrate assemblages.

644 Hydrological Processes, 14, 3161-317.

645 Armstrong, K.N., Storey, A.W. and Davies, P.M., 2005. Effects of catchment clearing 646 and sedimentation on macroinvertebrate communities of cobble habitat in freshwater 647 streams of southwestern Australia. Journal of the Royal Society of Western Australia, 648 88, 1-11. 
649 Bo, T., Fenoglio, S., Malacarne, G., Pessino, M. and Sgariboldi, F., 2007. Effects of 650 clogging on stream macroinvertebrates: an experimental approach. Limnologica-

651 Ecology and Management of Inland Waters, 37, 186-192.

652 Bona, F., Doretto, A., Falasco, E., La Morgia, V., Piano, E., Ajassa, R. and Fenoglio, 653 S., 2015. Increased sediment loads in alpine streams: an integrated field study. River 654 Research and Applications. 32, 1316-1326.

655 Bond N.R. and Downes B.J., 2003 The independent and interactive effects of fine 656 sediment and flow on benthic invertebrate communities characteristic of small upland 657 streams. Freshwater Biology, 48, 455-465

658 Buendia, C., Gibbins, C.N., Vericat, D. and Batalla, R.J., 2014. Effects of flow and 659 fine sediment dynamics on the turnover of stream invertebrate assemblages.

660 Ecohydrology, 7, 1105-1123.

661

662 Buendia, C., Gibbins, C.N., Vericat, D., Batalla, R.J. and Douglas, A., 2013.

663 Detecting the structural and functional impacts of fine sediment on stream 664 invertebrates. Ecological Indicators, 25, 184-196.

665

666

667

Burdon, F.J., McIntosh, A.R. and Harding, J.S., 2013. Habitat loss drives threshold 668 response of benthic invertebrate communities to deposited sediment in agricultural streams. Ecological Applications, 23, 1036-1047.

669 Carlson, P.E., Johnson, R.K. and McKie, B.G., 2013. Optimizing stream 670 bioassessment: habitat, season, and the impacts of land use on benthic 671 macroinvertebrates. Hydrobiologia, 704, 363-373.

672

673 Chevene, F., Doléadec, S. and Chessel, D., 1994. A fuzzy coding approach for the 674 analysis of long-term ecological data. Freshwater Biology, 31, 295-309.

675 Clarke K. and Gorley R., 2006. PRIMER v6: User manual/tutorial, Plymouth, UK: 676 Primer-E, Ltd. $190 \mathrm{p}$.

677 Clarke, R.T., 2013. Estimating confidence of European WFD ecological status class 678 and WISER Bioassessment Uncertainty Guidance Software (WISERBUGS).

679 Hydrobiologia, 704, 39-56.

680 Cline, L.D., Short, R.A. and Ward, J.V., 1982. The influence of highway construction 681 on the macroinvertebrates and epilithic algae of a high mountain stream.

682 Hydrobiologia, 96, 149-159.

683 Conroy, E., Turner, J.N., Rymszewicz, A., Bruen, M., O'Sullivan, J.J., Lawler, D.M., 684 Lally, H. and Kelly-Quinn, M., 2016 Evaluating the relationship between biotic and 685 sediment metrics using mesocosms and field studies. Science of The Total 686 Environment, 568, 1092-1101. 
687 Delucchi, C. M. and Peckarsky, B.L., 1989. Life history patterns of insects in an 688 intermittent and a permanent stream. Journal of the North American Benthological 689 Society, 8, 308-321.

690 Descloux, S., Datry, T. and Marmonier, P., 2013. Benthic and hyporheic invertebrate 691 assemblages along a gradient of increasing streambed colmation by fine sediment. 692 Aquatic Sciences, 75, 493-507.

693 Descloux, S., Datry, T. and Usseglio-Polatera, P., 2014. Trait-based structure of 694 invertebrates along a gradient of sediment colmation: Benthos versus hyporheos 695 responses. Science of the Total Environment, 466, 265-276.

696 Dewson, Z.S., James, A.B. and Death, R.G., 2007. A review of the consequences of 697 decreased flow for instream habitat and macroinvertebrates. Journal of the North 698 American Benthological Society, 26, 401-415.

699

700 Doretto, A., Bona, F., Falasco, E., Piano, E., Tizzani, P. and Fenoglio, S., 2016. Fine 701 sedimentation affects CPOM availability and shredder abundance in Alpine streams. 702 Journal of Freshwater Ecology, 31, 299-302.

703 Doretto, A., Bona, F., Piano, E., Zanin, I., Eandi, A.C. and Fenoglio, S., 2017. 704 Trophic availability buffers the detrimental effects of clogging in an alpine stream. 705 Science of The Total Environment. Doi: 10.1016/j.scitotenv.2017.03.108

706 Downes, B.J., Lake, P.S., Glaister, A. and Bond, N,R., 2006. Effects of sand 707 sedimentation on the macroinvertebrate fauna of lowland streams: are the effects 708 consistent?. Freshwater Biology, 51, 144-160.

709 Duan, X., Wang, Z., Xu, M. and Zhang, K., 2009. Effect of streambed sediment on 710 benthic ecology. International Journal of Sediment Research, 24, 325-338.

711 Fitter, R. and Manuel, R., 1986. Collins field guide to freshwater life. Collins: London, 712 UK.

713 Fraser, B.G., Williams, D.D. and Howard, K.W., 1996. Monitoring biotic and abiotic 714 processes across the hyporheic/groundwater interface. Hydrogeology Journal, 4, 3671550.

716 Friberg, N., 2014. Impacts and indicators of change in lotic ecosystems. Wiley 717 Interdisciplinary Reviews: Water, 1, 513-531.

718 Gayraud, S. and Philippe, M., 2001. Does subsurface interstitial space influence 719 general characteristics and features and morphological traits of benthic 720 macroinvertebrate communities in streams. Archiv für Hydrobiologie, 151, 667-686.

721 Göthe, E., Baattrup-Pedersen, A., Wiberg-Larsen, P., Graeber, D., Kristensen, E.A. 722 and Friberg, N., 2016. Environmental and spatial controls of taxonomic versus trait 723 composition of stream biota. Freshwater Biology. 62, 397-413. 
753

754

755

756

757

758

759

760

Higler, L.G., 1975. Reactions of some caddis larvae (Trichoptera) to different types of substrate in an experimental stream. Freshwater Biology, 5, 151-158.

Johnson, R.C., Carreiro, M.M., Jin, H.S. and Jack, J.D., 2012. Within-year temporal variation and life-cycle seasonality affect stream macroinvertebrate community structure and biotic metrics. Ecological Indicators, 13, 206-214.

Jones, I., Growns, I., Arnold, A., McCall, S. and Bowes, M., 2015. The effects of increased flow and fine sediment on hyporheic invertebrates and nutrients in stream mesocosms. Freshwater Biology, 60, 813-826.

Jones, J.I., Murphy, J.F., Collins, A.L., Sear, D.A., Naden, P.S. and Armitage, P.D., 2012. The impact of fine sediment on macro-invertebrates. River Research and Applications, 28, 1055-1071.

Jowett, I.G., 1997. Environmental effects of extreme flows. Floods and droughts: the New Zealand experience. New Zealand Hydrological Society, Wellington, 103-116.

Kaller, M.D. and Hartman, K.J., 2004. Evidence of a threshold level of fine sediment accumulation for altering benthic macroinvertebrate communities. Hydrobiologia, 518, 95-104.

Kreutzweiser, D.P., Capell, S.S. and Good, K.P., 2005. Effects of fine sediment inputs from a logging road on stream insect communities: a large-scale experimental approach in a Canadian headwater stream. Aquatic Ecology, 39, 55-66.

Laini, A., Vorti, A., Bolpagni, R. and Viaroli, P., 2014. Small-scale variability of benthic macroinvertebrates distribution and its effects on biological monitoring. In Annales de Limnologie-International Journal of Limnology, 50, 211-216.

Lamouroux, N., Dolédec, S. and Gayraud, S., 2004. Biological traits of stream macroinvertebrate communities: effects of microhabitat, reach, and basin filters. Journal of the North American Benthological Society, 23, 449-466.

Larsen, S. and Ormerod, S.J., 2010. Combined effects of habitat modification on trait composition and species nestedness in river invertebrates. Biological Conservation, 143, 2638-2646.

Larsen, S. and Ormerod, S.J., 2010. Low-level effects of inert sediments on temperate stream invertebrates. Freshwater Biology, 55, 476-486.

Larsen, S., Pace, G. and Ormerod, S.J., 2011. Experimental effects of sediment deposition on the structure and function of macroinvertebrate assemblages in temperate streams. River Research and applications, 27, 257-267. 
761

762

763

764

765

766

767

768

769

770

771

772

773

774

775

776

777

778

779

780

781

782

783

784

785

786

787

788

789

790

791

792

793

794

795

Larson, S., Vaughan, I.P. and Ormerod, S.J., 2009 Scale-dependant effects of fine sediment on temperature headwater invertebrates. Freshwater Biology, 54, 203-219.

Lemley, D. A., 1982. Modification of benthic insect communities in polluted streamscombined effects of sedimentation and nutrient enrichment. Hydrobiologia, 87, 229-245.

Lenat, D.R., Penrose, D.L. and Eagleson, K.W., 1979. Biological evaluation of nonpoint source pollutants in North Carolina streams and rivers. Biological Series no 102. North Carolina Department of Natural Resources and Community Development, Division of Environmental Management, Raleigh, USA.

Lenat, D.R., Penrose, D.L. and Eagleson, W., 1981. Variable effects of sediment addition on stream benthos. Hydrobiologia, 187-194.

Leopold L.B., Wolman M.G. and Miller J.P., 1964. Fluvial Processes in Geomorphology. Freeman, San Francisco, CA.

Logan, O.D., 2007. Effects of fine sediment deposition on benthic invertebrate communites. Masters of Science Thesis, The University of New Brunswick.

Mathers, K. L. and Wood, P. J., 2016. Fine sediment deposition and interstitial flow effects on macroinvertebrate community composition within riffle heads and tails. Hydrobiologia, 776, 147-160.

Mathers, K.L., Millett, J., Robertson, A.L., Stubbington, R. and Wood, P.J., 2014. Faunal response to benthic and hyporheic sedimentation varies with direction of vertical hydrological exchange. Freshwater Biology, 59, 2278-2289.

Mathers, K.L., Chadd, R.P, Dunbar, M.J, Extence, C.A, Reeds, J., Rice, S.P. and Wood, P.J., 2016 The long-term effects of invasive signal crayfish (Pacifastacus leniusculus) on instream macroinvertebrate communities. Science of the Total Environment. 556, 207-218.

Matthaei, C.D., Piggott, J.J. and Townsend, C.R., 2010. Multiple stressors in agricultural streams: interactions among sediment addition, nutrient enrichment and water abstraction. Journal of Applied Ecology, 47, 639-649.

Matthaei, C.D., Weller, F., Kelly, D.W. and Townsend, C.R., 2006. Impacts of fine sediment addition to tussock, pasture, dairy and deer farming streams in New Zealand. Freshwater Biology, 51, 2154-2172.

McCarthy, J. M., Hein, C. L., Olden, J. D. and Zanden, M. J. V. 2006. Coupling longterm studies with meta-analysis to investigate impacts of non-native crayfish on zoobenthic communities. Freshwater Biology, 51, 224-235. 
796

797

798

799

800

801

802

803

804

805

806

807

808

809

810

811

812

813

814

815

816

817

818

819

820

821

822

823

824

825

826

827

828

829

830

831

832

833

834

835

McNeil, W. J. and Ahnell, W. H., 1964. Success of pink salmon spawning relative to size of spawning bed materials (No. 157). US Department of Interior, Fish and Wildlife Service.

Menezes, S., Baird, D.J. and Soares, A.M., 2010. Beyond taxonomy: a review of macroinvertebrate trait-based community descriptors as tools for freshwater biomonitoring. Journal of Applied Ecology, 47, 711-719.

Milesi, S.V., Dolédec, S. and Melo, A.S., 2016. Substrate heterogeneity influences the trait composition of stream insect communities: an experimental in situ study. Freshwater Science, 35, 1321-1329.

Minshall, G. W., 1988. Stream ecosystem theory: A global perspective. Journal of the North American Benthological Society, 7, 263-288.

Monk, W.A., Wood, P.J., Hannah, D.M. and Wilson, D.A., 2008. Macroinvertebrate community response to inter-annual and regional river flow regime dynamics. River Research and Applications, 24, 988-1001.

Monk,W.A.,Wood, P.J., Hannah, D.M., Extence, C.A., Chadd, R.P., Dunbar, M.J., 2012. How does macroinvertebrate taxonomic resolution influence ecohydrological relationships in riverine ecosystems. Ecohydrology 5, 36-45.

Murphy, J.F. and Giller, P.S., 2000. Seasonal dynamics of macroinvertebrate assemblages in the benthos and associated with detritus packs in two low-order streams with different riparian vegetation. Freshwater Biology, 43, 617-631.

Pacioglu, O., Shaw, P. and Robertson, A., 2012. Patch scale response of hyporheic invertebrates to fine sediment removal in two chalk rivers, Archiv für Hydrobiologie, 181, 283-288.

Pardo, I. and Armitage, P.D., 1997. Species assemblages as descriptors of mesohabitats, Hydrobiologia, 344, 111-128.

Petticrew, E.L., Krein, A. and Walling, D.E., 2007. Evaluating fine sediment mobilization and storage in a gravel-bed river using controlled reservoir releases. Hydrological Processes, 21, 198-210.

Pilière, A.F.H., Verberk, W.C.E.P., Gräwe, M., Breure, A.M., Dyer, S.D., Posthuma, L., Zwart, D., Huijbregts, M.A.J. and Schipper, A.M., 2016. On the importance of trait interrelationships for understanding environmental responses of stream macroinvertebrates. Freshwater Biology, 61, 181-194.

Rabeni, C., Doisy, K. and. Zweig, L.D., 2005. Stream Invertebrate community functional responses to deposited sediment. Aquatic Sciences, 65, 395-402. 

an aquatic fine sediment biotic index. Environmental Management, 49, 242-252.

838 Rempel, L.L., Richardson, J.S. and Healey, M.C., 2000. Macroinvertebrate community structure along gradients of hydraulic and sedimentary conditions in a large gravel-bed river. Freshwater Biology, 45, 57-73.

Richards, C., Host, G.E. and Arthur, J.W., 1993. Identification of predominant environmental factors structuring stream macroinvertebrate communities within a large agricultural catchment. Freshwater Biology, 29, 285-294.

845 Southwood, T.R.E., 1977. Habitat, the templet for ecological strategies? Journal of 846 Animal Ecology, 46, 337-365.

847 Sutherland, A.B., Culp, J.M. and Benoy, G.A. 2012. Evaluation of deposited sediment and macroinvertebrate metrics used to quantify biological response to excessive sedimentation in agricultural streams. Environmental Management, 50: 50-63.

851

852

Statzner, B., Dolédec, S. and Hugueny, B., 2004. Biological trait composition of 853 European stream invertebrate communities: assessing the effects of various trait 854 filter types. Ecography, 27, 470-488.

855

856

857

Suren, A.M. and Jowett, I.G., 2001. Effects of deposited sediment on invertebrate 858 drift: an experimental study. New Zealand Journal of Marine and Freshwater

859

860 Research, 35, 725-737.

861

Tachet, H., Bournaud, M., Richoux, P. and Usseglio-Polatera, P., 2010. Invertébrés d'eau douce : Systématique, Biologie, Écologie. CNRS Editions, Paris.

862 Townsend, C.R. and Hildrew, A.G., 1994. Species traits in relation to a habitat 863 templet for river systems. Freshwater Biology, 31, 265-275.

864

865

866

Townsend, C.R., Uhlmann, S.S. and Matthaei, C.D., 2008. Individual and combined 867 responses of stream ecosystems to multiple stressors. Journal of Applied Ecology, 45, 1810-1819.

869

Turley, M.D., Bilotta, G.S., Chadd, R.P., Extence, C.A., Brazier, R.E., Burnside, N.G. and Pickwell, A.G., 2016. A sediment-specific family-level biomonitoring tool to 871 Indicators, 70, 151-165.

872 Twardochleb, L. A., Olden, J. D. and Larson, E. R., 2013 A global meta-analysis of 873 the ecological impacts of non-native crayfish. Freshwater Science. 32, 1367-138. 
874 Urbanič, G., Toman, M.J. and Krušnik, C., 2005. Microhabitat type selection of

875 caddisfly larvae (Insecta: Trichoptera) in a shallow lowland stream. Hydrobiologia,

876 541, 1-12.

877

878 Usseglio-Polatera, P., Bournaud, M., Richoux, P. and Tachet, H., 2000. Biological

879 and ecological traits of benthic freshwater macroinvertebrates: relationships and

880 definition of groups with similar traits. Freshwater Biology, 43, 175-205.

881

882 Wagenhoff, A., Townsend, C.R. and Matthaei, C.D., 2012. Macroinvertebrate

883 responses along broad stressor gradients of deposited fine sediment and dissolved

884 nutrients: a stream mesocosm experiment. Journal of Applied Ecology, 49, 892-902.

885 Waters, T.F., 1995. Sediment in streams: sources, biological effects, and control.

886 American Fisheries Society.

887 White, J. C., Hannah, D. M., House, A., Beatson, S. J. V., Martin, A., and Wood, P. 888 J., 2017. Macroinvertebrate responses to flow and stream temperature variability 889 across regulated and non-regulated rivers. Ecohydrology, 10, e1773.

890 Wood, P.J. and Armitage, P.D., 1997. Biological effects of fine sediment in the lotic 891 environment. Environmental management, 21, 203-217.

892 Wood, P.J., Boulton, A.J., Little, S. and Stubbington, R., 2010. Is the hyporheic zone 893 a refugium for aquatic macroinvertebrates during severe low flow conditions?. Archiv 894 für Hydrobiologie, 176, 377-390.

895 Wood, P.J., Armitage, P.D., Hill, M.J., Mathers, K.L. and Millett, J. 2016 Faunal 896 responses to fine sediment deposition in urban rivers. In Gilvear, D.J., Greenwood, 897 M.T., Thoms, M.C. and Wood, P.J. (Eds.) River Science: Research and 898 Management for the $21^{\text {st }}$ Century. John Wiley and Sons, Chichester.

899 Xu, M.Z., Wang, Z.Y., Pan, B.Z. and Zhao, N., 2012. Distribution and species 900 composition of macroinvertebrates in the hyporheic zone of bed sediment.

901 International Journal of Sediment Research, 27, 129-140. 